\title{
PENDIDIKAN AGAMA DI TENGAH PLURALISME BANGSA (DARI PARADIGMA EKSKLUSIF KE INKLUSIF)
}

\author{
Didik Komaidi
}

\begin{abstract}
Seeing the history of Indonesia recenly often appear the phenomenon of violence or conflict based on ethnic, religious, racial, inter-group and terrorism cases. This phenomenon compel us to rethink the role of religion, especifically religious education in the life of a pluralistic society. Viewing these facts would be a challenge for the clergy, scholars, including religious education stakeholders, to build a pluralistic society become tolerant, barmonious, and cooperative, and democratic. Then, education has a strategic role in design civil society civilization, especially the students. In the application, religious education must have an inclusive paradigm not exclusive. Inclusive paradigm is the paradigm of contextual education, tolerance, respect for differences religius, racial, intergroup, and cooperate live. In other hand the exlusive paradigm is the educational paradigm that is less respect for differences, underestimate to others, just think of the group, less tolerant.
\end{abstract}

Keywords: Religious education, pluralism, exclusive paradigm, inclusive.

\section{A. Pendahuluan}

"Agama, hari-hari ini, adalah sebuah nama yang terkesan membuat gentar dan cemas. Agama--di tangan para pemeluknya belakangan ini-sering tampil dengan wajah kekerasannya, dan bersamaan itu seolah-olah telah kehilangan wajah ramahnya," demikian tulis sebuah pamlet diskusi buku Kala Agama jadi Bencana karya Charles Kimball. ${ }^{1}$ Potret itu dipertegas lagi dengan kasus terorisme, bom bunuh diri, konflik antar agama, bunuh diri massal atas nama agama yang semakin mengentalkan citra agama yang begitu keras.

Kemudian kita pun bertanya-tanya, ada apa dengan agama? Adakah agama mengandung unsur-unsur yang melegitimasi kekerasan, bahkan teror? Apakah agama berperan sebagai sumber problem atau sumber solusi? Bagaimana mengenali terjadinya pembusukan di tubuh agama? Apa yang

1 Tulisan ini saya temukan dalam pamlet undangan diskusi buku Kala Agama jadi Bencana karya Charles Kimball (2004) terbitan Mizan yang bertempat di Bentara Budaya Yogyakarta. 
(masih) tersisa dari agama? Pertanyaan-pertanyaan itu perlu diajukan untuk mengkritisi makna agama di tengah pergaulan antar masyarakat.

Melihat sejarah Indonesia di mana seringkali muncul fenomena kekerasan/konflik yang berbasis SARA (baca: suku, agama, ras, dan antar golongan), agaknya menarik perhatian kita untuk berpikir ulang tentang peran agama, lebih khusus pendidikan agama, dalam mewarnai kehidupan masyarakat. Seperti peristiwa konflik etnis, konflik antar umat beragama, konflik kepentingan antar kelompok/golongan, dan sebagainya. Selain konflik SARA tersebut, yang tidak kalah memprihatinkan adalah fenomena deviasi/dekadensi moral dan etika bangsa seperti KKN (kolusi, korupsi dan nepotisme), perkelahian antar pelajar, penyalahgunaan Narkoba, seks bebas, kriminalitas, dan sebagainya. Hal itu menunjukkan bahwa masyarakat kita sedang sakit. Bukan sakit dalam arti fisik seperti malaria, HIV, dsb., tetapi sakit dalam arti psikis/moral seperti korupsi, kriminalitas, kemaksiatan, dsb.

Melihat kenyataan tersebut tentu saja menjadi tantangan bagi para agamawan, cerdik-cendikia, termasuk peran pendidikan agama, dalam membangun masyarakat yang pluralis ini menjadi toleran, rukun, dan demokratis menuju masyarakat Madani (berperadaban). Maka di sini tidak terelakkan peran pendidikan agama sangat dibutuhkan. Pendidikan agama baik di bidang agama itu sendiri maupun kemasyarakatan tetap memiliki nilai strategis dalam menciptakan blue printe (cetak biru) bagi pengembangan masyarakat kita. Sebuah blue printe yang merekayasa perkembangan masyarakat (social engineering) ke arah yang lebih baik, damai, toleran, demokratis, dan sejahtera sebagai masyarakat yang sehat. Di mana ciri masyarakat yang sehat adalah sebuah masyarakat yang walaupun berbedabeda namun mampu hidup bekerjasama dan rukun. ${ }^{2}$

Dalam realitas Indonesia yang multi SARA di atas, peran pendidikan agama tetap signifikan dan strategis. Karena, pendidikan agama bisa berperan secara lebih dini di sekolah-sekolah di mana generasi muda mendapat pewarisan (internalisasi) nilai-nilai luhur dari generasi tua atau ajaran agamanya sehingga nilai-nilai itu akan memberikan bekal pengetahuan/prinsip-prinsip dalam menjalani masa depannya.

Melihat fenomena kekerasan/konflik berbasis SARA yang masih seringkali muncul di tengah kita, termasuk penyimpangan moral, tentu saja kita harus berpikir ulang tentang paradigma pendidikan agama kita dalam perannya untuk menciptakan keberagamaan masyarakat yang religius.

${ }^{2}$ Erich Fromm, 1997, Masyarakat yang Sehat, Jakarta, Yayasan Obor, cetakan pertama. 
Selain pendidikan agama, tidak kalah penting adalah kita perlu memperhatikan kualitas pendidikan nasional kita. Dunia pendidikan nasional kita masih memerlukan perhatian ekstra. Sebab, fakta menunjukkan bahwa kualitas pendidikan sekaligus SDM kita ternyata masih rendah dan tertinggal apalagi kalau dibanding dengan negara-negara lain. Menurut laporan yang dibuat oleh Political and economic Risk consultancy (PERC, 2001) Indonesia berada pada peringkat ke 12 dari 12 negara di Asia dalam hal mutu pendidikan. Sementara Filipina peringkat ke-9, Malaysia ke-7, India ke-5, dan Singapura ke-2. Studi lainnya juga dilakukan oleh United Nations Development Programme (UNDP, 2003) tentang human development index (HDI) secara langsung menunjukkan rendahnya mutu pendidikan Indonesia. Di sini Indonesia menempati peringkat ke-112 dari 174 negara. Sementara negara-negara jiran menempati peringkat yang lebih baik seperti Malaysia, Singapura, Filipina, Thailand, dan lainnya. ${ }^{3}$

Kenyataan-kenyataan tersebut membuat kita bertanya sejauh mana kualitas pendidikan nasional kita saat ini? Termasuk bagaimana kualitas pendidikan agama kita? Bagaimana perannya di tengah kehidupan masyarakat kita? Bagaimana urgensinya dalam dinamika kehidupan bangsa ini? Sudah tepatkah paradigma pendidikan agama, metode, kurikulum, anggaran yang proporsional, fasilitas, SDM, dan sejenisnya. Tulisan ini dengan segala keterbatasannya berusaha untuk mengurai benang kusut persoalan tersebut sambil mencari solusinya.

\section{B. Landasan Ideil dan Konstitusional}

Secara konstitusional, sesungguhnya pendidikan agama memiliki kedudukan yang kuat yakni, merujuk pada: (1) dasar Negara kita Pancasila terutama sila pertama: Ketuhanan Yang Maha Esa; (2) Undang-Undang Dasar 1945 pasal 28 dan 29 tentang HAM dan hak beragama; (3) UndangUndang no. 20 tahun 2003 tentang sistem Pendidikan Nasional.

Pertama, sila pertama dari Pancasila berbunyi: Ketuhanan Yang Maha Esa dengan dukungan sila-sila lainnya menunjukkan bahwa faktor ketuhanan (transenden) memiliki kedudukan tinggi sebagai landasan bagi silasila lainnya. Artinya apapun aktivitas kita baik dalam konteks kemasyarakatan dan kenegaraan-kebangsaan harus dilandasi oleh sila pertama Ketuhanan Yang Maha Esa. Sila-sila dalam Pancasila merupakan sari pati yang digali para founding fathers bangsa ini dari ajaran nenek moyang

${ }^{3}$ Ki Supriyoko, 2004, Remang-Remang Masa Depan Pendidikan Nasional, Media Indonesia, edisi 10 Agustus 2004.

LITERASI, Volume. V, No. 1 Juni 2014 
sebagai landasan untuk menciptakan sebuah Negara dan sebagai common platform dalam bermasyarakat, berbangsa, dan bernegara.

Pasal tersebutlah yang secara spesifik memberikan dasar hukum bagi pelaksanaan pendidikan agama di setiap jenjang pendidikan. Dengan asas legalitas tersebut semua pihak terutama lembaga pendidikan baik negeri atau swasta harus mematuhi dan melaksanakan aturan tersebut dan tidak ada alasan untuk menghindarinya. Ketentuan-ketentuan yang dinyatakan dalam Undang-Undang tersebut konsekuensinya tentu mempunyai kekuatan hukum dan daya paksa kepada setiap warganya untuk menaati dan melaksanakan aturan-aturan tersebut, tidak hanya pada tingkat konsep tetapi juga pelaksanaannya di lapangan.

Sebenarnya, di samping landasan konstitusional tersebut, yang tak kalah penting adalah kenyataan bangsa Indonesia sebagai masyarakat yang religius. Indonesia juga dikenal bukan Negara agama, tetapi juga bukan Negara sekuler. Artinya adalah nilai-nilai agama tetap penting dan sangat mewarnai perilaku dan alam pemikiran masyarakat Indonesia meskipun Negara bukan berdasar agama tertentu sehingga nilai-nilai agama memiliki kedudukan yang istimewa di benak bangsa Indonesia. Dengan kata lain, masyarakat Indonesia dikenal sebagai masyarakat yang religius sehingga peran agama (pendidikan agama) menjadi hal yang tak terelakkan.

Dengan dasar ideil dan konstitusional tersebut dan sifat masyarakatnya yang agamis, menjadi tak terelakkan bagi kita sebagai bangsa Indonesia untuk tetap memperhatikan pendidikan agama. Posisi pendidikan agama tetap menjadi pilar penting dalam ikut mewarnai tata dan pola hidup bermasyarakat dan bernegara. Oleh karena itu, pendidikan agama tetap dianggap penting dan perlu dipertahankan serta diperbaiki kualitasnya.

Dalam hal filosofi pendidikan Indonesia, para perintis pendidikan bangsa, teristimewa Ki Hajar Dewantoro, merasa perlu untuk menandaskan bahwa pendidikan kita harus berpedoman pada "kebudayaan Timur yang luhur." Seperti pembentukan karakter atau sikap dasar moral dan budi pekerti ditambah semangat perjuangan menjadi bagian utama. ${ }^{4}$ Dengan kata lain, boleh saja secara metodologis mengadopsi dari Barat, tetapi filosofi dasar harus tetap berdasar pada kebudayaan Timur, karena berbeda nilainilai dengan Bangsa lain.

\section{Urgensi Pendidikan Agama: Moralitas Bangsa}

${ }^{4}$ Romo Mangun Wijaya, 1999, Saya Ingin Membayar Hutang kepada Rakyat, Yogyakarta, Kanisius, cetakan I.

82

LITERASI, Volume. V, No. 1 Juni 2014 
Dalam kehidupan manusia tidak bisa terlepas dari aspek keagamaan yang memang menjadi bagian dari sifat manusia. Bahwa manusia di samping bersifat jasmani, tetapi juga ruhani-spiritual. Jadi kehidupan keagamaan merupakan refleksi dari sifat ruhani-spiritual manusia. Jadi, fakor agama merupakan bagian integral pada diri manusia, terlepas apakah pemeluk itu taat atau tidak.

Namun demikian, masalah keagamaan ini pada kenyataannya mengandung paradoks. Dalam arti bahwa kadang masalah agama bisa merekatkan hubungan antar manusia, tetapi ia juga bisa menimbulkan permusuhan antar manusia karena perbedaan (pemahaman) agamanya, tidak hanya antar agama, tetapi juga internal agama. Konflik keagamaan tersebut begitu nyata menghiasi sejarah kemanusiaan seperti kasus perang Salib, konflik Islam-Hindu di India, konflik antar sekte Sunni-Syiah di Pakistan, konflik Ambon, terorisme, dsb.

Problem-problem keagamaan dan moralitas masyarakat begitu kompleks, terutama akar-akar kekerasan religius sehingga harus ditelusuri. Charles Kimbahll (2004), pakar sejarah dan perbandingan (Yahudi-KristenIslam), berusaha menelusuri dan memetakan problem/konflik berbasis keagamaan tersebut. Dengan peta analisisnya, pengarang tersebut berhasil menjelaskan fenomena kekerasan religius dewasa ini. Sebagai jalan keluarnya, Kimball mengimbau kita agar kembali ke agama autentik. Yakni, modus keberagamaan yang tidak sekedar bersetia dengan doktrin skriptural yang statis, tetapi sebuah iman yang hidup dan menghidupi kemanusiaan universal. $^{5}$

Para pemikir keagamaan berusaha meramu formula yang tepat bagaimana mengurangi konflik berbasis agama tersebut, tidak hanya Islam, tetapi juga Kristen, Hindu, Budha, Yahudi, dsb. Sehingga memunculkan ide toleransi, kerukunan, pluralisme, dan sebagainya sebagai upaya untuk mencegah/mengurangi konflik yang bersifat keagamaan yang kadang begitu dahsyat dan berdarah-darah. Upaya menciptakan kehidupan yang plural, namun tetap rukun, damai, dan toleran menjadi penting.

Terlepas dari paradoks tersebut, jelas bahwa hanya agama-lah yang senantiasa menjaga penegakan moralitas Iman dan tingkah laku yang luhur bagi umatnya. Ketika telah terjadi internalisasi nilai-nilai ajaran agama kepada hati sanubari dan merasuk di dalamnya maka akan menjadi pegangan dan pedoman kehidupan sehari-hari. Dalam konteks sosial bisa dilihat

${ }^{5}$ Charlces Kimbahll, 2004, Kala Agama Jadi Bencana, Bandung, Mizan, cetakan pertama.

LITERASI, Volume. V, No. 1 Juni 2014 
bahwa kelompok keagamaanlah yang senantiasa menjaga kehidupan masyarakat sampai kehidupan kenegaraan agar tetap berjalan dalam koridor nilai-nilai agama dan tidak menyimpang darinya.

Jadi fungsi agama sebagai sang penjaga moral/etika masyarakat yang adiluhung inilah yang harus senantiasa dipertahankan dan dipelihara dengan baik sehingga perilaku warga masyarakat tetap dalam koridor moralitas dan iman yang benar. Maka di sinilah pendidikan agama sebagai media pewarisan nilai-nilai agama menjadi penting dan bermakna bagi manusia dan kemanusiaan serta tidak bisa dihilangkan begitu saja. Hal itu sesuai pendapat Christoper J Lukas (1984) yang mengatakan bahwa pendidikan tidak hanya terkait dengan aspek transfer of knowledge (pengalihan pengetahuan), tetapi juga terkait dengan aspek yang lebih luas, yakni aspek perubahan nilai dan pandangan hidup. Dengan demikian, melalui pendidikan-lah diharapkan dapat terjadi perubahan secara mendasar pada aspek moralitas, budaya, kesejahteraan, dan sebagainya, seperti dikutip Ngainum Naim. ${ }^{6}$

\section{Dari Paradigma Eksklusif ke Inklusif}

Perbedaan (pluralisme) bangsa ini harus disikapi secara arif dan bijaksana. Perbedaan merupakan hal yang lumrah dan keniscayaan sejarah serta tidak bisa dihindari. Termasuk pemahaman terhadap ajaran agama. Kebenaran mutlak memang ada dalam agama tetapi tidak bisa memutlakkan/memaksakan kepada orang lain. Pemaksaan kebenaran terhadap pihak lain tentunya akan menimbulkan konflik dengan pihak lain. Oleh karena itu, benar pernyataan Mohammad Sobary dalam Spiritualitas Baru: Agama dan Aspirasi Rakyat (1994) yang menyatakan bahwa:

Sudah pasti bahwa ada kebenaran mutlak dalam agama. Siapa meragukan ini mungkin ateis. Bila dia mengaku seorang pemeluk agama juga, dia tentu bukan pemeluk yang baik. Dia pendeknya bukan orang saleh. Tetapi dalam komunikasi antar budaya, mungkin kita tak bisa memutlakkan kebenaran itu sebab begitu kebenaran mutlak tadi diserahkan Tuhan ke tangan kita untuk menata kehidupan, segera jadi ragu adakah kita telah mengoperasikan kebenaran tadi dengan benar. ${ }^{7}$

Dalam konteks Indonesia, unsur keagamaan begitu kental dalam mewarnai kehidupan sosial-politik. Unsur keagamaan kadang bisa

${ }^{6}$ Ngainum Naim, 2004, Krisis Moralitas dan Tanggung-Jawab Dunia Pendidikan, MPA edisi Juli 2004, Surabaya.

${ }^{7}$ Mohammad Sobary, 1994, Spiritualitas Baru: Agama dan Aspirasi Rakyat, Yogyakarta, Dian Interfide, cetakan I. 
menimbulkan konflik yang tak kalah dahsyatnya di antara kelompok masyarakat. Di sinilah faktor keagamaan mengandung paradoks. Di satu sisi agama bisa menimbulkan energi perekat antar manusia, tetapi di sisi lain, bisa menimbul energi perpecahan di antara golongan masyarakat.

Oleh karena itu, untuk menghindari dan mencegah benturan antar kelompok masyarakat yang berbeda agama menjadi pekerjaan besar dan urgen. Boleh saja orang berbeda agama, tetapi janganlah sampai bermusuhan dan menumpahkan darah. Dari pemikiran itulah muncul gagasan tentang paradigma eksklusif dan inklusif. Yang dimaksud paradigma adalah cara pandang atau cara pikir dalam melihat sesuatu sebagai piranti dalam ilmu filsafat, Hardono Hadi. ${ }^{8}$

Pertama, eksklusif adalah sebuah pemahaman keagamaan yang ketat dan kaku. Ia memahami dan memandang orang lain dengan cara yang hitamputih, mukmin-kafir, halal-haram, dan sejenisnya secara ketat-kaku dan fanatisme buta. Begitu juga dalam kehidupan sosial-politik, golongan ini kurang bisa berhubungan dan bekerja sama dengan kelompok lain. Mereka mudah menyalahkan atau mengkafirkan orang lain yang tidak sepaham dengan golongannya. Dengan pemahaman yang rigid (kaku) ini tentu saja akan mudah menimbulkan konflik sosial antar kelompok masyarakat yang berbeda-beda. Dalam konteks Negara Kesatuan RI, tentu bisa menimbulkan konflik disintegrasi nasional yang mengancam stabilitas sosial-politik dan keamanan.

Kedua, inklusif adalah suatu pemahaman yang utuh dan komprehensif terhadap suatu ajaran agama. Pemahaman ini tetap melihat bahwa dalam suatu agama ada kebenaran mutlak, namun demikian ia tidak bisa dipaksakan kepada orang lain. Ia mampu memegang nilai-nilai kebenaran agamanya, namun juga mampu bekerjasama dengan orang/umat lain secara toleran dan harmonis, tanpa melanggar ajaran keimanan, tanpa kehilangan jati diri dan identitas kelompoknya. Ia mampu hidup dengan harmonis dalam internal kelompoknya, namun juga bisa hidup berdampingan dengan harmonis dengan kelompok yang berbeda. Di sini yang dipentingkan adalah suasana harmonis dan kondusif bagi kehidupan bersama secara damai dan toleran.

Dalam kehidupan masyarakat Indonesia yang plural ini, tentu saja sikap hidup yang inklusif sangat diperlukan dalam hidup bersama. Sementara sikap hidup eksklusif harus dijauhi karena akan menimbulkan prasangka,

${ }^{8}$ Hardono Hadi, 1994, Epistemologi: Filsafat Pengetahuan, Yogyakarta, Kanisius, cetakan pertama.

LITERASI, Volume. V, No. 1 Juni 2014 
permusuhan, dan disintegrasi. Jadi pemahaman keagamaan, termasuk pendidikan agama, harus ditekankan pada sikap inklusifitas. Artinya, kita boleh berbeda pemahamanan dan keyakinan agama, namun tetap bisa hidup rukun dan damai. Sikap yang serba kaku dan mudah menyalahkan pihak lain akan mengganggu keharmonisan hidup bersama baik dalam bermasyarakat, berbangsa, dan bernegara.

Sikap hidup yang toleran (inklusif) seperti itu juga digambarkan dalam AlQur'an surat Al-Kafirun dan Piagam Madinah yang dirancang Nabi Muhammad SAW bersama dengan suku-suku lain di kota Madinah pada zamannya. Di mana piagam Madinah itu mengajarkan bahwa perbedaan dalam hal agama, suku, budaya, dan politik bukanlah sesuatu yang salah dan merupakan hal yang lumrah, namun jangan sampai mengganggu kerukunan dan persatuan masyarakat. Perbedaan (pluralisme) harus dimaknai secara bijak dan tepat agar kedamaian, kerjasama sosial, kerukunan masyarakat tetap terwujud dan langgeng. Meminjam istilah AA Gym, dai kondang, perbedaan dan kebersamaan itu sama-sama indahnya kalau kita mampu mengelolanya secara positif.

\section{E. Praksis Pendidikan Agama}

Praksis pendidikan agama di sini menyangkut hal-hal teknis mengenai kurikulum dan metode pengajaran yakni bagaimana proses kegiatan belajar dilaksanakan secara baik dan benar. Termasuk anggaran yang proporsional dalam mengelola pengajaran agama. Sehingga upaya untuk mengajarkan pendidikan agama bisa tercapai secara efektif dan efisien.

Pendidikan agama merupakan sarana utama, dan dengannya nilainilai agama diperkenalkan baik kepada individu maupun kepada masyarakat. Di samping itu, pendidikan agama juga menciptakan iklim, suasana, bahkan rangsangan nilai konkret di dalam hidup untuk mengalami atau menghayati nilai-nilai tertentu. Lewat pengajaran dan penghayatan, pendidikan agama berusaha membina mentalitas iman dalam diri para penganutnya.

Tentu saja, supaya dapat membina mentalitas dan mempengaruhi alam dan aku perspektif, pendidikan agama tidak boleh hanya berbentuk pengajaran agama atau pengalihan pengetahuan tentang agama. Pengalihan pengetahuan agama bisa menghasilkan pengetahuan dan ilmu dalam diri orang yang diajar, tetapi pengetahuan ini belum menjamin pengarahan

9 J. Riberu, 2001, Pendidikan: Kegelisahan Sepanjang Zaman, Yogyakarta, Kanisius.

86

LITERASI, Volume. V, No. 1 Juni 2014 
manusia yang bersangkutan untuk hidup sesuai dengan pengetahuan tersebut. Bahkan pengalihan pengetahuan agama seringkali berbentuk pengalihan rumus-rumus doktrin dan kaidah-kaidah susila. Oleh karena itu, pengajaran agama menghasilkan pengetahuan hafalan yang melekat di bibir dan hanya mewarnai kulit, tetapi tidak mampu mempengaruhi orang mempelajarinya.

Melihat fakta sosial di mana banyak konflik bernuansa agama, maka pendidikan agama harus direvisi dari konsep indoktrinasi menjadi relevansi. Artinya adalah pendidikan agama harus dikembangkan bukan hanya indoktrinasi berupa ajaran surga-neraka, baik-buruk, halal-haram, mukminkafir, tetapi juga relevansinya yakni berkaitan dengan kehidupan sehari-hari sehingga akan bisa dihayati dan diamalkan. Pendidikan agama harus mengajarkan pengetahuan menjadi pengetahuan yang fungsional, artinya pengetahuan yang membantu orang untuk menanggapi, menilai, dan menentukan sikap dalam hidup. Oleh karena itu, pengajaran agama sebaiknya bertitik tolak dari dan dikaitkan kepada situasi hidup konkret sehari-hari, seperti bagaimana berpikir dan bertindak baik untuk diri sendiri maupun untuk orang lain, berhubungan dengan orang lain, bermasyarakat, toleransi, hidup dalam masyarakat plural, dan sejenisnya.

Dari segi metode pengajaran, hendaknya hubungan guru dan murid bersifat dialogis-komunikatif. Guru tidak dipandang sebagai satu-satunya sumber belajar, murid bukan sebagai obyek pengajaran. Namun guru dan murid sama-sama sebagai subyek belajar sehingga suasana belajar di kelas akan dinamis dan hidup. Di sini metode pengajaran hadap masalah yang dikembangkan oleh Paulo Freire (2001) menarik dipakai dalam mengembangkan pemikiran anak dalam pemecahan masalah. Di sini pendidikan bisa dimaknai sebagai pemberdayaan manusia agar mandiri dan kreatif. $^{10}$

Jadi, pengajaran pendidikan agama tidak hanya dipahami hanya sebagai transfer pengetahuan saja, tetapi juga penghayatan dan pengamalan dalam kehidupan sehari-hari. Di mana ajaran agama pada gilirannya mencapai relevansinya dengan alam nyata, bukan hanya alam akhirat/ghaib.

Selain faktor kurikulum dan metode, menurut temuan Ahmad Ramadhan dalam penelitiannya (1998) adalah faktor anggaran yang memadai, kualitas SDM, kurangnya fasilitas bagi pengembangan pendidikan agama. Lanjutnya, selama ini masih ada kesan marginalisasi pendidikan agama di tengah pendidikan pengetahuan umum. Oleh karena itu, harus

10 Paulo Freire dan Ira Shor, 2001, Menjadi Guru Merdeka: Petikan Pengalaman, Yogyakarta, LkiS, Cetakan I.

LITERASI, Volume. V, No. 1 Juni 2014 
segera ada pembenahan dan solusi permasalahan tersebut demi perbaikan kaulitas pendidikan agama kita. Contoh konkret adalah anggaran lembaga pendidikan di Departemen Pendidikan Nasional dan Departemen Agama sungguh timpang. ${ }^{11}$

Pertanyaannya adalah bagaimana harus meningkatkan mutu dan bersaing, kalau modal dasarnya/ anggaran saja tidak imbang. Dalam jangka panjang, hendaknya persoalan anggaran di dua lembaga itu baik di tingkat dasar sampai perguruan tinggi harus diseimbangkan kalau kualitas pendidikan di semua lembaga pendidikan ingin ditingkatkan. Persoalan anggaran tersebut menjadi uneg-uneg atau gerundelan di tengah masyarakat. Pendeknya, segala persoalan yang menyelimuti pendidikan agama tersebut harus diselesaikan di mana pada gilirannya akan meningkatkan kualitas pendidikan nasional kita.

\section{E. Pendidikan Multi Kultural}

Dalam konteks Indonesia yang majemuk dari segi suku, agama, budaya, bahasa dan kepentingan politiknya, kurikulum pendidikan agama harus memberikan materi pendidikan multi kultural, yakni materi yang memberikan landasan pengetahuan tentang bagaimana seorang individu hidup di tengah masyarakat yang majemuk (plural) tersebut. Generasi muda harus diajarkan bagaimana cara hidup seorang warga di tengah pluralisme bangsanya. Artinya, ia mampu hidup baik dalam internal kelompoknya maupun dalam eksternal kelompok lain. Ia selalu bisa hidup damai dengan lingkungannya.

Dalam konteks pengajaran, Peserta didik harus diajarkan tentang bagaimana memaknai perbedaan (pluralisme) dalam bingkai bhineka tunggal ika secara bijaksana dan tepat. Sebuah generasi yang mampu memahami jati dirinya baik dalam lingkup internal golongannya, agamanya, sukunya, budayanya, dan sebagainya, maupun dalam lingkup eksternal dengan golongan lain yang berbeda suku, agama, budaya, kepentingan politik, dan sebagainya. Pendeknya, generasi yang mampu beradaftasi dan hidup dengan berbagai golongan berbeda namun tetap tidak terlepas dari akar budaya, agama, dan jati dirinya, serta mampu hidup damai dalam masyarakat yang plural.

Kemudian dari segi out put, menurut H.A.R Tilaar, lulusan pendidikan yang diidealkan adalah educated and civilized buman being yakni,

11 Ahmad Ramadhan, 1998, The Place of Islamic Education in the National Education System in Indonesia, Tesis S2, Leiden University.

88

LITERASI, Volume. V, No. 1 Juni 2014 
manusia terpelajar/berpengetahuan dan berbudaya. Manusia macam itu hanya dapat dihasilkan oleh suatu sistem pendidikan yang berakar dalam kebudayaan. $^{12}$

\section{F. Indonesia Baru dan Masyarakat Madani}

Akhir-akhir ini kita sering mendengar pernyataan tentang masyarakat Madani. Masyarakat madani atau disebut juga civil society adalah sebuah masyarakat memiliki kesadaran dalam bersosial dan berpolitik serta memiliki peradaban yang menjaga hak-hak warga sipil. Sejak gerakan reformasi 1998, terasa muncul suatu perubahan besar di Indonesia yang menandai dinamika masyarakat dan bangsa kita.

Hal itu menunjukkan di dalam masyarakat dan Negara terjadi perubahan/dinamika. Dalam hal ini Soedjatmoko (2001) berpendapat:

...ciri utama kehidupan sosial ialah proses perubahan yang dialami masyarakat Indonesia. Sebagian proses masyarakat itu terdiri dari perubahan-perubahan yang disengaja atau perubahan yang dituju secara sadar, yaitu usaha pembangunan kita, dan sebagian lagi terdiri dari perubahan-perubahan di dalam masyarakat yang terjadi secara otomatis dan tidak seluruhnya dapat dikendalikan oleh masyarakat atau pemerintah. ${ }^{13}$

Lebih lanjut, katanya: Pembangunan merupakan usaha untuk meningkatkan kesejahteraan umum menuju masyarakat adil dan makmur dengan cara meningkatkan produksi dan produktivitas, mengubah struktur masyarkat Indonesia, serta memodernisasikan proses dan hubungan produksi sedemikian rupa sehingga seluruh potensi bangsa Indonesia dapat berkembang. Tujuan pembangunan bukan hanya untuk meningkatkan GNP, melainkan untuk mengubah struktur masyarakat guna menegakkan keadilan sosial.

Kemudian Bagaimana kedudukan agama dan masyarakat? J. Riberu menulis dalam Pendidikan: Kegelisaban Sepanjang Zaman (2001):

Setiap kelompok manusia yang hidup bersama dalam suatu masyarakat selalu memiliki tata tertib hidup yang diatur oleh patokanpatokan yang mengendalikan dan mengarahkan tingkah laku individu dalam masyarakat dan tingkah laku masyarakat sebagai masyarakat.

${ }^{12}$ H.A.R Tilaar, 2004, Paradigma Baru Pendidikan Nasional, Jakarta, Penerbit Rineka Cipta, cetakan pertama.

${ }^{13}$ Lihat Soedjatmoko dalam Pendidikan: Kegelisaban Sepanjang Zaman, Editor Sindunata Yogyakarta, Kanisius. 
Patokan-patokan ini merupakan suatu tata hidup yang sering diungkapkan dalam tata hukum dan tata susila, baik tertulis maupun lisan. ${ }^{14}$

Menurut, seorang filosuf, manusia kalau ingin menjadi baik dan berbuat luhur, harus berpengetahuan. Di sinilah peran pendidikan agama sangat signifikan untuk mendesain pola pikir, cara pandang, pandangan hidup bagi generasi muda agar diwarnai oleh nilai-nilai agama yang luhur dan budaya bangsa sendiri yang adiluhung bagi kemajuan dan kesejahteraan negeri.

Dalam masyarakat madani dan negara modern, hubungan antara warga dengan negara (baca: pemerintah) diatur secara demokratis. Termasuk pemilihan pemimpin, bukan ditentukan oleh keturunan tetapi oleh kemampuan dan penerimaan masyarakat. hubungan warga dan pemerintah berkedudukan setara. Semua pihak harus tunduk pada aturan-aturan sebagai konsensus bersama dalam hidup bermasyarakat, berpolitik, dan bernegara. ${ }^{15}$

Barangkali inilah bentuk ideal sebuah masyarakat madani yang terinspirasi dari negara kota Madinah yang dilandasi oleh piagam Madinah. Sebuah masyarakat yang plural, namun bisa hidup damai, rukun, dan sejahtera.

\section{G. PENUTUP}

Setelah menguraikan pendidikan agama dengan berbagai perspektif hukum dan sifat bangsa Indonesia sendiri, terdapat kesimpulan bahwa masyarakat Indonesia yang religius dan pendidikan agama memang tidak bisa terpisahkan. Di mata masyarakat Indonesia, agama dan pendidikan agama menjadi suatu keniscayaan sejarah dan sosial. Artinya hal itu harus ada dalam proses hidupnya baik dalam konteks bermasyarakat, berbangsa, dan bernegara. Pendeknya, pendidikan agama merupakan sesuatu yang mutlak bagi kehidupan warga masyarakat negeri ini.

Namun demikian, pendidikan agama harus bisa memberikan kontribusi yang positif bagi pembangunan negeri ini. Artinya, pendidikan agama harus bisa memberikan warna yang damai dan rukun kepada setiap

\footnotetext{
${ }^{14}$ Lihat J. Riberu dalam Pendidikan: Kegelisahan Sepanjang Zaman, Editor Sindunata Yogyakarta, Kanisius.

${ }^{15}$ Nurcholis Madjid, 1999, Cita-cita Politik Islam Era Reformasi, Jakarta, Paramadina, cetakan I.
} 
warga Negara yang plural di negeri. Sebab, bukankah warga masyarakat negeri ini memang majemuk (plural) sehingga wacana perbedaan dan kebersamaan harus dikembangkan dalam rangka hidup bersama. Makna bhineka tunggal ika harus dipahami secara positif dan tidak kaku. Dalam arti, kita harus menghargai perbedaan, namun harus tetap menjaga kebersamaan dan persatuan bangsa.

Oleh karena itu, pendidikan agama harus bisa memberikan pencerahan kepada semua umatnya, agar ajaran agama tidak dipahami sebagai legitimasi dalam permusuhan dengan pihak lain. Dalam konteks pengajaran, ajaran agama harus dirancang bukan hanya sebuah indoktrinasi melulu, tetapi juga memiliki relevansi dengan kehidupan konkret sehari-hari. Sehingga agama bukan hanya persoalan "langit", tetapi juga "membumi" dalam alam nyata kehidupan sehari-hari.

Dalam kehidupan keluarga besar Indonesia yang plural ini, maka penting adanya pendidikan agama yang memperhatikan pendidikan multi kultural, yakni pendidikan yang mengajarkan tentang pentingnya memaknai perbedaan dalam SARA (suku, agama, ras, dan antar golongan) secara bijak dan positif sehingga masih tetap dalam koridor persatuan dan kesatuan dalam NKRI.

Dengan pendidikan agama yang tepat dan benar, dalam jangka panjang akan memberikan kontribusi yang positif bagi kemajuan dan kesejahteraan negeri ini. Sehingga dengan demikian, makna agama sebagai rahmatan lil'alamin bisa mencapai maknanya di seluruh alam. 


\section{DAFTAR PUSTAKA}

Hardono Hadi, 1994, Epistemologi: Filsafat Pengetahuan, Yogyakarta, Kanisius, cetakan pertama.

Mohammad Sobary, 1994, Spiritualitas Baru: Agama dan Aspirasi Rakyat, Yogyakarta, Dian Interfide, cetakan I.

Erich Fromm, 1997, Masyarakat yang Sehat, Jakarta, Yayasan Obor, cetakan pertama.

Ahmad Ramadhan, 1998, The Place of Islamic Education in the National Education System in Indonesia, Tesis S2, Leiden University.

Nurcholis Madjid, 1999, Cita-cita Politik Islam Era Reformasi, Jakarta, Paramadina, cetakan I.

Romo Mangun Wijaya, 1999, Saya Ingin Membayar Hutang kepada Rakyat, Yogyakarta, Kanisius, cetakan I.

J. Riberu, 2001, Pendidikan: Kegelisahan Sepanjang Zaman, Yogyakarta, Kanisius.

Sindunata, Editor, 2001, Pendidikan: Kegelisahan Sepanjang Zaman, Yogyakarta, Kanisius

Paulo Freire dan Ira Shor, 2001, Menjadi Guru Merdeka: Petikan Pengalaman, Yogyakarta, LkiS, Cetakan I.

Mas'ud, Abdurrahman, 2004, Menggagas Format Pendidikan Nondikotomik: Humanisme Religius sebagai Paradigma Pendidikan Islam, Yogyakarta, Gama Media, Cetakan pertama.

Kimball, Charlces, 2004, Kala Agama Jadi Bencana, Bandung, Mizan, cetakan pertama.

H.A.R Tilaar, 2004, Paradigma Baru Pendidikan Nasional, Jakarta, Penerbit Rineka Cipta, cetakan pertama.

Ngainum Naim, 2004, Krisis Moralitas dan Tanggung-Jawab Dunia Pendidikan, MPA edisi Juli 2004, Surabaya.

Ki Supriyoko, 2004, Remang-Remang Masa Depan Pendidikan Nasional, Media Indonesia, edisi 10 Agustus 2004. 